\title{
PREDICTIVE RELEVANCE OF DIFFERENT CLINICAL AND LABORATORY FINDINGS FOR HIGHER MORTALITY IN PATIENTS WITH COVID-19 IN A SINGLE CENTER COHORT: NEUTROPHIL/ LYMPHOCYTE RATIO, HIGH CRP, GGT AND CREATININE LEVELS ARE ASSOCIATED WITH HIGH MORTALITY
}

\author{
COVID-19'DA KLINIK VE LABORATUVAR BULGULARININ MORTALITE GOSTERGESI \\ OLARAK DEĞERI, TEK MERKEZ KOHORT ÇALIŞMASI, YÜKSEK NOTROFIL/LENFOSIT \\ ORANI, CRP, GGT, KREATININ DEĞGRLERI VE ARTMIŞ MORTALITE RISKI
}

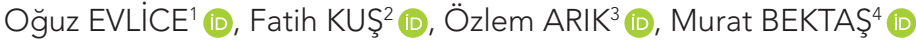 \\ ${ }^{1}$ Kutahya University of Health Sciences School of Medicine, Department of Infectious Diseases and Clinical Microbiology, Kutahya, Turkey \\ 2Patnos State Hospital, Department of Internal Medicine, Ağrı, Turkey \\ ${ }^{3}$ Kutahya University of Health Sciences School of Medicine, Department of Biostatistics, Kutahya, Turkey \\ ${ }^{4}$ Istanbul University, Istanbul Faculty of Medicine, Department of Rheumatology, Istanbul, Turkey
}

ORCID IDs of the authors: O.E. 0000-0001-6939-0367; F.K. 0000-0003-1650-154X; Ö.A. 0000-0002-9427-3733; M.B. 0000-0002-1788-3837

Cite this article as: Evlice O, Kus F, Arik O, Bektas M. Predictive relevance of different clinical and laboratory findings for higher mortality in patients with COVID-19 in a single center cohort: neutrophil/lymphocyte ratio, high CRP, GGT and creatinine levels are associated with high mortality. J Ist Faculty Med. Published online February 3, 2022. doi: 10.26650/IUITFD.896789

\section{ABSTRACT}

Objective: Early detection of mortality risk is important in patients diagnosed with of coronavirus disease 2019 (COVID-19). Therefore, we aimed to evaluate the predictive value of different clinical and laboratory parameters in disease severity and mortality in patients with COVID-19.

Materials and Methods: Patients admitted to hospital with a diagnosis of COVID-19 were evaluated retrospectively. The patients' admission date, discharge date, intensive care transfer/ death date, contact history, smoking, symptoms at the time admission, vital markers at admission, and laboratory parameters were recorded.

Results: The study included a total of 347 patients, of whom $168(48.4 \%)$ were women. The mean age of the patients was $59.69 \pm 16.87$ (14-97) years, while $40.9 \%(n=142)$ were aged over 65 years. Overall, $10.1 \%(n=35)$ of the patients required transfer to an intensive care unit and $8.4 \%(n=29)$ were deceased. When clinical parameters were evaluated at the time of admission, oxygen saturation was found to be lower in the group that died. $(79.51 \pm 6.95)$ compared to the survivors $(88.78 \pm 6.11)(p<0.001)$. Additionally, male gender $(p=0.05)$, advanced age $(p<0.001)$,

\section{ÖZET}

Amaç: Koronavirüs hastalığı 2019 (COVID-19) tanısı ile takip edilen hastalarda mortalite riskinin erken tespiti önemlidir. COVID-19'da farklı klinik ve laboratuvar parametrelerin hastalık şiddeti ve mortalite göstergesi olarak değerinin saptanması hedeflenmiştir.

Gereç ve Yöntem: COVID-19 tanısı ile hastaneye yatırılan hastalar retrospektif olarak değerlendirilmiştir. Hastaların yatış tarihi, taburculuk tarihi, yoğun bakıma sevk ve ölüm tarihleri, başvuru sırasındaki semptomları, başvuru anındaki klinik ve laboratuvar parametreleri kaydedilmiştir.

Bulgular: Çalışmaya 168'i $(\% 48,4)$ kadın olmak üzere toplam 347 hasta dahil edildi. Hastaların yaş ortalaması 59,69 $\pm 16,87$ (14-97) $\% 40,9^{\prime} u$ ( $\left.n=142\right) 65$ yaşın üzerindeydi. Hastaların \%10,1'i $(n=35)$ yoğun bakım ünitesine transfer edildi ve \%8.4'ü $(n=29)$ öldü. Başvuru anındaki klinik paremetreler değerlendirildiğinde, oksijen saturasyonu ölen grupta $(79,51 \pm 6,95)$ sağ kalanlara göre daha düşüktü $(88,78 \pm 6,11)(p<0,001)$. Erkek cinsiyet $(p=0,05)$, ileri yaş $(p<0,001)$, pozitif PCR sonucu $(p=0,036)$, şiddetli toraks BT tutulumu $(p<0,001)$ ve en az bir komorbidite varlığı $(p=0,003)$ mortalite grubunda daha fazlaydı. Çok değişkenli analizlerde

Corresponding author/iletişim kurulacak yazar: oguzevlice@hotmail.com

Submitted/Başvuru: 22.04.2021 • Revision Requested/Revizyon Talebi: 30.07.2021 •

Last Revision Received/Son Revizyon: 12.11.2021 • Accepted/Kabul: 29.11.2021 • Published Online/Online Yayın: 03.02.2022 
positive PCR result $(p=0.036)$, congestive heart failure $(p=0.044)$, severe COVID-19 involvement on thorax CT $(p<0.001)$, and presence of at least one comorbidity $(p=0.003)$ were observed at a higher rate in the mortality group. In the multivariate analyses, increased values of the NLR (HR: 1.04, 95\% Cl: 1.00-1.08), creatinine (OR: 1.37, 95\% Cl: 1.13-1.66), CRP (=-0.18, OR: 0.98, 95\% Cl: 0.97-0.99), GGT (OR: 1.006, 95\% Cl: 1.001-1.012), age (OR: 5.67, 95\% Cl: 2.24-14.38), male gender (OR: 2.38, 95\% Cl: 0.98-5.75), and presence of any comorbidity (OR: $5.23,95 \% \mathrm{Cl}: 2.08-13.13$ ) were associated with mortality.

Conclusions: Several clinical and laboratory parameters, such as advanced age, male gender, presence of any comorbidity, and NLR, GGT, CRP and creatinine levels at the time of admission can predict mortality in COVID-19 patients. These parameters obtained at the time of admission can contribute to the reduction of mortality through a closer clinical and laboratory follow-up in these patients.

Keywords: COVID-19, mortality, mortality risk factors, gamma-glutamyl transferase, neutrophil/lymphocyte ratio, SARSCoV-2 artmış nötrofil/lenfosit oranı (HR: 1,04, \%95 GA: 1,00-1,08), kreatinin (OR: 1,37, \%95 Cl: 1,13-1,66), CRP (=-0,18, OR: 0,98, 95) \% GA: 0,97-0,99), GGT (OR: 1,006, \%95 GA: 1,001-1,012), yaş (OR: 5,67, \%95 GA: 2,24-14,38), erkek cinsiyet (OR: 2,38, \%95 GA: 0,98 $-5,75)$ ve komorbidite varlığı (OR: 5,23, \%95 GA: 2,08-13,13) mortalite ile ilişkili bulundu.

Sonuç: COVID-19'da ileri yaş, erkek cinsiyet, komorbidite varlığı ve başvuru anındaki artmış NLR, GGT, CRP ve kreatinin değerleri gibi çeşitli klinik ve laboratuvar parametreler mortaliteyi öngörmede yardımcı olabilir. Başvuru anında elde edilen bu parametrelerle belirlenen hastaların daha yakın klinik ve laboratuvar takibi mortalitenin azaltılmasına katkı sağlayacaktır.

Anahtar Kelimeler: COVID-19, mortalite, mortalite misk maktörleri, gama-glutamil transferaz, nötrofil/lenfosit oranı, SARSCov-2

\section{INTRODUCTION}

In November 2019, a new coronavirus called "severe acute respiratory syndrome coronavirus 2" (SARS-CoV-2) was identified in Wuhan, China (1,2). Coronavirus disease 2019 (COVID-19) caused by the virus can lead to a wide clinical variability from mild diseases to acute respiratory failure and death (3). With the emergence of SARS-CoV-2 in Wuhan and its spread across the world, COVID-19 has become a global problem and resulted in the deaths of millions of people. Several risk factors, such as male gender, advanced age, and diabetes have been associated with high mortality in patients with COVID-19 in previous studies $(4,5)$. In addition, there have been some efforts to determine biomarkers that can indicate prognosis and mortality related to the disease. Laboratory parameters, such as IL-6, D-dimer, C-reactive protein (CRP), and absolute lymphocyte count are some of these biomarkers that have been found to have prognostic significance (4-6).

Neutrophil/lymphocyte ratio (NLR) can be easily calculated by dividing the absolute neutrophil count by the absolute lymphocyte count in routine blood tests and appears to be a useful biomarker because it is applicable in almost every laboratory. In a study by Liu et al., NLR was identified as an independent risk factor of mortality in patients followed up in hospital with a diagnosis of COVID-19, as well as other routine laboratory parameters (7).

In this study, we aimed to evaluate the prognostic importance of routine laboratory parameters and NLR in the prediction of severe disease and mortality in patients with COVID-19.

\section{MATERIALS AND METHODS}

\section{Study design and participants}

Patients over 18 years who presented to our hospital and received a probable or definitive diagnosis of COVID-19 between July 1, 2020 and October 1, 2020 were included in the study. Cases were defined according to the World Health Organization definitions (8). A positive result in the SARS-CoV-2 real-time reverse-transcription polymerase chain reaction (RT-PCR) test of a respiratory tract sample was defined as a definite diagnosis, while appearance consistent with viral pneumonia in thoracic computed tomography (CT) together with appropriate clinical findings was accepted as a probable case despite a negative SARS-CoV-2 RT-PCR test.

All the patients were treated with hydroxychloroquine and/or favipiravir. Dexamethasone $8 \mathrm{mg}$ or equivalent was applied to patients with an oxygen saturation $\left(\mathrm{SpO}_{2}\right)$ of $<90 \%$ at the time of admission and/or during follow-up. The patients who developed secondary bacterial infections were evaluated on daily rounds and treated with antibiotics, if necessary.

The study was approved by the local ethics committee of Ağrı Education and Research Hospital (Date: 11.12.2020, No: 29).

\section{Data collection}

Demographic data, accompanying diseases, laboratory and lung $\mathrm{CT}$ findings of the patients were retrospectively obtained from the hospital information system. For the patients who were transferred to other intensive care unit (ICU) centers, the mortality status was screened for using the National Death Notification System. 
The patients' admission date, discharge date, ICU transfer/death date, contact history, smoking, symptoms during admission, vital markers at admission, complete blood count, urea, creatinine, aspartate aminotransferase (AST), alanine aminotransferase (ALT), total bilirubin, lactate dehydrogenase (LDH), creatine kinase (CK), D-dimer, ferritin, troponin and CRP values, the highest values of ferritin and CRP and the lowest lymphocyte count during the follow-up, and lymphocyte count at discharge were recorded. Hydroxychloroquine, favipiravir and steroid use for the treatment of COVID-19 and antibiotic use for the treatment of secondary infections were also noted. In thorax CT, cases with ground glass densities of over three foci or greater than $3 \mathrm{~cm}$ diameter or the presence of consolidation were classified as moderate pneumonia, and those with the involvement of all lobes in both lungs and at least three lesions larger than $3 \mathrm{~cm}$ in diameter were classified as severe pneumonia (9).

\section{Statistical analysis}

All the data were analyzed using the Statistical Package for the Social Sciences (SPSS) software package for
Windows (v 21.0; IBM, Armonk, NY, USA). Individual and aggregated data were summarized using descriptive statistics, including mean, standard deviation and median (min-max) values, frequency distributions and percentages. The normality of data distribution was verified with the Kolmogorov-Smirnov test. Comparison of the variables with a normal distribution was performed with Student's t-test. Variables which were not normally distributed were compared between the groups using the Mann Whitney $\mathrm{U}$ and Kruskal-Wallis tests. Evaluation of categorical variables was performed with the chi-square test. Correlation analysis was performed using the Pearson or Spearman test according to the normality of data distribution. $p$ values of $<0.05$ were considered statistically significant.

\section{RESULTS}

\section{Demographic features}

The study included a total of 347 patients, of whom 168 $(48.4 \%)$ were women. The mean age of the patients was $59.69 \pm 16.87$ (14-97) years, while $40.9 \%(n=142)$ were over 65 years. Of the patients, $30.8 \%(n=107)$ had a history of

Table 1: Baseline clinical features of the patients hospitalized with COVID-19

\begin{tabular}{|c|c|c|c|}
\hline & Clinical variables & Number (n) & Percent (\%) \\
\hline Gender & $\begin{array}{l}\text { Male } \\
\text { Female }\end{array}$ & $\begin{array}{l}179 \\
168\end{array}$ & $\begin{array}{l}51.5 \\
49.5\end{array}$ \\
\hline Age (year) & $\begin{array}{l}<65 \\
\geq 65\end{array}$ & $\begin{array}{l}205 \\
142\end{array}$ & $\begin{array}{l}59 \\
41\end{array}$ \\
\hline PCR status & $\begin{array}{l}\text { Negative } \\
\text { Positive }\end{array}$ & $\begin{array}{l}96 \\
251\end{array}$ & $\begin{array}{l}27.6 \\
72.3\end{array}$ \\
\hline ICU admission & $\begin{array}{l}\text { No } \\
\text { Yes }\end{array}$ & $\begin{array}{c}312 \\
35\end{array}$ & $\begin{array}{l}90 \\
10\end{array}$ \\
\hline Tobacco use & $\begin{array}{l}\text { Absent } \\
\text { Present }\end{array}$ & $\begin{array}{c}307 \\
30\end{array}$ & $\begin{array}{l}89 \\
11\end{array}$ \\
\hline HT & $\begin{array}{l}\text { Absent } \\
\text { Present }\end{array}$ & $\begin{array}{l}200 \\
147\end{array}$ & $\begin{array}{l}57.7 \\
42.3\end{array}$ \\
\hline DM & $\begin{array}{l}\text { Absent } \\
\text { Present }\end{array}$ & $\begin{array}{c}258 \\
89\end{array}$ & $\begin{array}{l}74.4 \\
25.6\end{array}$ \\
\hline COPD/asthma & $\begin{array}{l}\text { Absent } \\
\text { Present }\end{array}$ & $\begin{array}{c}281 \\
66\end{array}$ & $\begin{array}{l}81 \\
19\end{array}$ \\
\hline Coronary artery disease & $\begin{array}{l}\text { Absent } \\
\text { Present }\end{array}$ & $\begin{array}{c}297 \\
50\end{array}$ & $\begin{array}{l}85.6 \\
14.4\end{array}$ \\
\hline Malignancy & $\begin{array}{l}\text { Absent } \\
\text { Present }\end{array}$ & $\begin{array}{c}344 \\
3\end{array}$ & $\begin{array}{l}99.2 \\
0.8\end{array}$ \\
\hline Acute renal failure & $\begin{array}{l}\text { Absent } \\
\text { Present }\end{array}$ & $\begin{array}{c}340 \\
7\end{array}$ & $\begin{array}{c}98 \\
2\end{array}$ \\
\hline Hydroxychloroquine treatment & $\begin{array}{l}\text { Absent } \\
\text { Present }\end{array}$ & $\begin{array}{l}184 \\
163\end{array}$ & $\begin{array}{c}53.1 \\
46.9 \%\end{array}$ \\
\hline Favipiravir treatment & $\begin{array}{l}\text { Absent } \\
\text { Present }\end{array}$ & $\begin{array}{l}100 \\
247\end{array}$ & $\begin{array}{l}28.8 \% \\
71.2 \%\end{array}$ \\
\hline
\end{tabular}

PCR: Polymerase chain reaction, ICU: Intensive care unit, HT: Hypertension, DM: Diabetes mellitus, COPD: Chronic obstructive pulmonary disease 
contact with a positive COVID-19 case and 72\% ( $n=250)$ had a positive COVID-19 RT-PCR test. The most common complaint was fatigue/myalgia at a rate of $71.2 \%(n=247)$, followed by cough (59.4\%), shortness of breath (53.6\%), fever $(36.0 \%)$, and headache (18.4\%). When the risk factors of the patients were evaluated, the presence of at least one comorbidity was observed in $13.8 \%(n=48)$ of the patients. The baseline clinical and laboratory parameters of the patients are summarized in Table 1.

Overall, $10.1 \%(n=35)$ of the patients required transfer to ICU and $8.4 \%(n=29)$ died. When the clinical parameters were evaluated at the time of admission, oxygen saturation was found to be lower in the mortality group (79.51 \pm 6.95$)$ compared to the survivors $(88.78 \pm 6.11)(p<0.001)$. In the univariate analysis, male gender $(p=0.054)$, advanced age $(p<0.001)$, a positive PCR result $(p=0.036)$, congestive heart failure $(p=0.044)$, severe COVID-19 involvement in thorax CT $(p<0.001)$, and presence of at least one comorbidity $(p=0.003)$ were observed at a significantly higher rate among the patients that developed mortality. The comparison of the clinical and laboratory parameters of the patients is presented in Table 2.

\section{Laboratory parameters at the time of admission}

There was a statistically significant increase in the leukocyte, neutrophil and NLR values among the patients who were deceased ( $p=0.03,0.03$, and 0.001 , respectively). Furthermore, the serum urea $(p<0.001)$, creatinine $(p<0.001), \operatorname{LDH}(p<0.001), \operatorname{AST}(p<0.001), \operatorname{ALT}(p=0.02)$, GGT $(p=0.046)$, D-dimer $(p=0.002)$ and troponin $(p<0.001)$ values were significantly higher in the mortality group compared to the survivors. Additionally, the mortality group had increased CRP (104.2 vs 57.6 mg/L; $p=0.001$ ) and ferritin (589.5 vs $375.0 \mathrm{ng} / \mathrm{mL}$ ) levels but lower lymphocyte $(0.95$ vs $1.4 \times 109 / \mathrm{L})$ values $(p=0.001,<0.001$, and $=0.001$, respectively) (Table 2 ).

In the correlation analysis, NLR was slightly positively correlated with age $(r=0.173, p=0.001)$ and CRP $(r=0.106$, $\mathrm{p}=0.049$ ) and moderately negatively correlated with $\mathrm{SpO}_{2}$ $(r=-0.437, p<0.001)$. A mild negative correlation was observed between CRP and $\mathrm{SpO}_{2}(r=-0.152, p=0.005)$ and a moderate positive correlation between CRP and GGT $(r=0.325, p<0.001)$. There was no correlation between the remaining clinical and laboratory parameters.

\section{Evaluation of risk factors for mortality}

In the multivariate analyses (forward logistic regression method), increased NLR [odds ratio (OR): 1.034, 95\% confidence interval (Cl): 1.003-1.066], advanced patient age (OR: 1.097, 95\% Cl: 1.054-1.14), presence of any comorbidity (OR: 12.74, 95\% Cl: 3.36-48.3), male gender (OR: 3.48, 95\% Cl: 1.28-9.47), and high creatinine (OR: 1.37, 95\% Cl: 1.13-1.66), CRP (=0.018, OR: $1.018,95 \% \mathrm{Cl}$ : 1.005-1.032) and GGT (OR: 1.006, 95\% Cl: 1.001-1.012) levels were associated with mortality (Table 3). Although the serum ferritin, BUN, ALT, AST, D-dimer and troponin levels were higher in the mortality group according to the univariate analysis, none of these parameters were associated with mortality in the multivariate analysis.

\section{DISCUSSION}

In this study, the rates of ICU admission (10.1\%) and mortality (8.4\%) were found to be lower compared to previous studies. In a study by Liu et al. including 245 patients, the mortality rate was reported to be $13.4 \%$ (7), and in a multicenter study with 1,859 patients, it was determined as $11.1 \%(10)$.

Several risk factors associated with a severe disease course and high mortality have been previously described in patients with COVID-19. In a multicenter retrospective study, several parameters such as age, number of comorbidities, cancer history, shortness of breath, change of consciousness, radiological involvement, and elevated laboratory parameters (NLR, LDH, and direct bilirubin) were included in risk scoring to evaluate the risk of progression to critical illness in patients hospitalized with COVID-19. It was stated that this scoring, performed at the time of hospital admission, could predict progression to critical illness (11). In a study conducted in China, advanced age, male gender, and hypertension were found to be associated with mortality (12). Similarly, in another study with 3,988 patients, advanced age, male gender, and the presence of chronic obstructive pulmonary disease and diabetes mellitus as comorbidities were identified as risk factors for higher mortality (13). Similarly, in the current study, older age, presence of at least one comorbidity, and male gender were associated with higher mortality.

When the laboratory parameters were evaluated, NLR, serum CRP and ferritin levels were higher among the mortality group than the survivors. NLR and increased inflammatory markers and their association with poor prognosis have also been defined in many diseases, such as liver cirrhosis and cerebrovascular events and malignancy (14-18). Additionally, it has been reported that NLR can be used as a supporting finding for the pneumonia severity score in patients followed up with a diagnosis of pneumonia in terms of infectious diseases (19). Neutrophils, along with lymphocytes, play an important role in the response to viral infections (20). Patients diagnosed with COVID-19 who have a high neutrophil count at the time of admission have an up to eight-fold higher risk of progression to severe disease (21). More than one mechanism contributes to the occurrence of lymphopenia in COVID-19. SARS-CoV-2 can cleave lymphocytes by attaching to angiotensin-converting enzyme (ACE) receptors expressed by lymphocytes. The cytokine storm that occurs with the increase in inflammatory mediators can trigger lymphocyte apoptosis. In addition, cytokine acti- 
Table 2: Comparison of the clinical and laboratory parameters between the patients with and without mortality

\begin{tabular}{|c|c|c|c|c|}
\hline $\begin{array}{l}\text { Clinical and Laboratory Findings } \\
\text { (mean } \pm \text { SD) }\end{array}$ & $\begin{array}{c}\text { Total } \\
n=347\end{array}$ & $\begin{array}{c}\text { Non-mortality group } \\
n=318(91.6 \%)\end{array}$ & $\begin{array}{l}\text { Mortality group } \\
n=29(8.4 \%)\end{array}$ & $\mathrm{p}$-value \\
\hline Body temperature $\left({ }^{\circ} \mathrm{C}\right)$ & $36.83 \pm 0.73$ & $36.83 \pm 0.74$ & $36.84 \pm 0.65$ & 0.666 \\
\hline Oxygen saturation $\left(\mathrm{SpO}_{2}\right)$ & $88.00 \pm 6.69$ & $88.78 \pm 6.11$ & $79.51 \pm 6.95$ & $<0.001$ \\
\hline Systolic BP (mmHg) & $119.08 \pm 14.89$ & $118.87 \pm 14.67$ & $122.10 \pm 17.08$ & 0.233 \\
\hline Diastolic BP (mmHg) & $72.76 \pm 10.58$ & $72.76 \pm 10.56$ & $72.75 \pm 10.98$ & 0.585 \\
\hline Hemoglobin (g/L) & $13.69 \pm 0.87$ & $13.70 \pm 1.91$ & $13.52 \pm 1.46$ & 0.279 \\
\hline Platelet (x109/L) & $193.86 \pm 80.33$ & $196.06 \pm 82.05$ & $170.40 \pm 54.01$ & $0.136^{*}$ \\
\hline WBC count (106/uL) & $7.40 \pm 8.97$ & $7.25 \pm 9.24$ & $9.05 \pm 4.89$ & $0.032^{*}$ \\
\hline Neutrophil count (x109/L) & $5.44 \pm 0.54$ & $5.27 \pm 5.45$ & $7.34 \pm 4.87$ & $0.030^{*}$ \\
\hline Lymphocyte count (x109/L) & $1.36 \pm 0.765$ & $1.40 \pm 0.78$ & $0.95 \pm 0.46$ & $0.001^{*}$ \\
\hline Neutrophil /lymphocyte ratio & $5.72 \pm 8.78$ & $5.23 \pm 8.40$ & $11.03 \pm 11.06$ & $<0.001 *$ \\
\hline BUN (mg/dL) & $46.26 \pm 34.46$ & $43.34 \pm 31.40$ & $78.27 \pm 48.56$ & $<0.001 *$ \\
\hline Creatinine $(\mathrm{mg} / \mathrm{dL})$ & $1.18 \pm 1.03$ & $1.13 \pm 1.01$ & $1.66 \pm 1.06$ & $<0.001 *$ \\
\hline Glucose $(\mathrm{mg} / \mathrm{dL})$ & $135.21 \pm 62.96$ & $133.41 \pm 59.59$ & $154.53 \pm 92.24$ & $0.123^{\star}$ \\
\hline $\mathrm{AST}(\mathrm{U} / \mathrm{L})$ & $38.29 \pm 33.60$ & $33.89 \pm 17.36$ & $86.59 \pm 88.92$ & $<0.001 *$ \\
\hline ALT (U/L) & $30.21 \pm 28.49$ & $27.94 \pm 18.75$ & $55.07 \pm 73.14$ & $0.023^{*}$ \\
\hline GGT (IU/L) & $49.83 \pm 62.28$ & $47.37 \pm 53.88$ & $76.72 \pm 119.00$ & $0.046^{\star}$ \\
\hline $\mathrm{LDH}(\mathrm{mg} / \mathrm{dL})$ & $313.12 \pm 146.00$ & $299.26 \pm 123.10$ & $465.22 \pm 255.80$ & $<0.001 *$ \\
\hline CRP (mg/L) & $61.53 \pm 85.12$ & $57.63 \pm 87.29$ & $104.20 \pm 34.79$ & $<0.001 *$ \\
\hline Ferritin (ng/mL) & $329.60 \pm 335.80$ & $305.82 \pm 317.90$ & $589.52 \pm 415.50$ & $<0.001 *$ \\
\hline$D$-dimer $(\mu \mathrm{g} / \mathrm{mL})$ & $0.70 \pm 1.16$ & $0.70 \pm 1.21$ & $0.76 \pm 0.64$ & $0.021 *$ \\
\hline \multirow[t]{2}{*}{ Troponin (ng/l) } & $32.54 \pm 333.7$ & $9.36 \pm 30.17$ & $285.82 \pm 1135.40$ & $<0.001^{*}$ \\
\hline & Clinical variables & $\begin{array}{c}\text { Patients alive } \\
\text { n (\%) }\end{array}$ & $\begin{array}{c}\text { Patients exitus } \\
\text { n (\%) }\end{array}$ & $\begin{array}{c}\text { p-value } \\
\text { (Odds ratio) }\end{array}$ \\
\hline Gender (n, \%) & $\begin{array}{l}\text { Male } \\
\text { Female }\end{array}$ & $\begin{array}{l}159(50.0 \%) \\
159(50.0 \%)\end{array}$ & $\begin{array}{l}20(69.0 \%) \\
9(31.0 \%)\end{array}$ & 0.054 \\
\hline Age (years) (mean $\pm S D)$ & $59.7 \pm 16.9$ & $58.34 \pm 16.4$ & $74.5 \pm 14.4$ & $<0.001 *$ \\
\hline Age $(n, \%)$ & $\begin{array}{l}<65 \text { year } \\
\geq 65 \text { year }\end{array}$ & $\begin{array}{l}198(62.3 \%) \\
120(37.7 \%)\end{array}$ & $\begin{array}{c}7(24.1 \%) \\
22(75.9 \%)\end{array}$ & $\begin{array}{l}<0.001 \\
(15.9)\end{array}$ \\
\hline $\operatorname{PCR}(n, \%)$ & $\begin{array}{l}\text { Negative } \\
\text { Positive }\end{array}$ & $\begin{array}{l}93(29.2 \%) \\
225(70.8 \%)\end{array}$ & $\begin{array}{c}3(10.7 \%) \\
25(89.3 \%)\end{array}$ & $0.03(4.74)$ \\
\hline Intensive care unit (n, \%) & $\begin{array}{l}\text { No } \\
\text { Yes }\end{array}$ & $\begin{array}{c}302(95.0 \%) \\
16(5.0 \%)\end{array}$ & $\begin{array}{l}10(34.5 \%) \\
19(65.5 \%)\end{array}$ & $<0.001$ \\
\hline Tobacco use (ever) (n, \%) & $\begin{array}{l}\text { Absent } \\
\text { Present }\end{array}$ & $\begin{array}{l}280(88.1 \%) \\
36(11.3 \%)\end{array}$ & $\begin{array}{c}27(93.1 \%) \\
2(6.9 \%)\end{array}$ & 0.617 \\
\hline Hypertension (n, \%) & $\begin{array}{l}\text { Absent } \\
\text { Present }\end{array}$ & $\begin{array}{l}186(58.5 \%) \\
132(41.5 \%)\end{array}$ & $\begin{array}{l}14(48.3 \%) \\
15(51.7 \%)\end{array}$ & 0.287 \\
\hline Diabetes mellitus ( $n, \%$ ) & $\begin{array}{l}\text { Absent } \\
\text { Present }\end{array}$ & $\begin{array}{l}236(74.2 \%) \\
82(25.8 \%)\end{array}$ & $\begin{array}{l}22(75.9 \%) \\
7(24.1 \%)\end{array}$ & 0.846 \\
\hline COPD/asthma (n, \%) & $\begin{array}{l}\text { Absent } \\
\text { Present }\end{array}$ & $\begin{array}{c}260(81.8 \%) \\
58(18.2 \%)\end{array}$ & $\begin{array}{l}21(72.4 \%) \\
8(27.6 \%)\end{array}$ & 0.220 \\
\hline Coronary artery disease (n, \%) & $\begin{array}{l}\text { Absent } \\
\text { Present }\end{array}$ & $\begin{array}{c}274(86.2 \%) \\
44(13.8 \%)\end{array}$ & $\begin{array}{c}23(79.3 \%) \\
6(20.7 \%)\end{array}$ & 0.225 \\
\hline Malignancy (n, \%) & $\begin{array}{l}\text { Absent } \\
\text { Present }\end{array}$ & $\begin{array}{c}315(99.1 \%) \\
3(0.9 \%)\end{array}$ & $\begin{array}{c}29(100.0 \%) \\
0(0.0 \%)\end{array}$ & 0.769 \\
\hline CT findings $(n, \%)$ & $\begin{array}{l}\text { Moderate involvement } \\
\text { Severe involvement }\end{array}$ & $\begin{array}{l}229(73.4 \%) \\
83(26.6 \%)\end{array}$ & $\begin{array}{c}9(31.0 \%) \\
20(69.0 \%)\end{array}$ & $<0.001$ \\
\hline Any comorbidity (n, \%) & $\begin{array}{l}\text { Absent } \\
\text { Present }\end{array}$ & $\begin{array}{c}280(88.1 \%) \\
38(11.9 \%)\end{array}$ & $\begin{array}{l}19(65.5 \%) \\
10(34.5 \%)\end{array}$ & $0.003(11.3)$ \\
\hline
\end{tabular}

BP: Blood pressure, WBC: White blood cell, BUN: Blood urea nitrogen, ALT: Alanine aminotransferase, AST: Aspartate aminotransferase, GGT: Gamma-glutamyl transferase, LDH: Lactate dehydrogenase, CRP: C-reactive protein, PCR: Polymerase chain reaction, COPD: Chronic obstructive pulmonary disease, CT: Computer tomography, SD: Standard deviation, $p<0.05$ statistically significant,

*: Mann-Whitney U test=Mortality-Non-mortality 
Table 3: Multivariate analysis of mortality-associated factors with the forward logistic regression method

\begin{tabular}{lcccc}
\hline Variables & $\mathrm{Bj}$ & $\mathrm{OR}$ & $95 \% \mathrm{Cl}$ & $\mathrm{p}$-value \\
Neutrophil/lymphocyte ratio (NLR) & 0.033 & 1.034 & $\mathbf{1 . 0 0 3 - 1 . 0 6 6}$ & $\mathbf{0 . 0 3 ^ { * }}$ \\
Age (years) & 0.093 & 1.097 & $\mathbf{1 . 0 5 4 - 1 . 1 4}$ & $<0.00$ * $^{*}$ \\
Gender (male) & 1.25 & 3.48 & $\mathbf{1 . 2 8 - 9 . 4 7}$ & $\mathbf{0 . 0 1 5 ^ { * }}$ \\
Any comorbidity & 2.55 & 12.74 & $\mathbf{3 . 3 6 - 4 8 . 3}$ & $<0.001^{*}$ \\
Creatinine (mg/dL) & 0.314 & 1.37 & $\mathbf{1 . 1 3 - 1 . 6 6}$ & $\mathbf{0 . 0 0 1 *}$ \\
CRP (mg/L) & 0.018 & 1.018 & $\mathbf{1 . 0 0 5 - 1 . 0 3 2}$ & $\mathbf{0 . 0 0 8 ^ { * }}$ \\
GGT (IU/L) & 0.006 & 1.006 & $\mathbf{1 . 0 0 1 - 1 . 0 1 2}$ & $\mathbf{0 . 0 2 2 ^ { * }}$ \\
Constant & -10.211 & 0.00 & & $<0.001^{*}$
\end{tabular}

*: statistically significant at $\mathrm{p}<0.05$. OR: Odds ratio, Cl: Confidence interval, CRP: C-reactive protein, GGT: Gamma-glutamyl transferase, Bj: Regression coefficient

vation impairs lymphocyte proliferation and turnover by affecting lymphoid organs (22). In a previous study, it was shown that a decrease in the CD8+ T lymphocyte count and interleukin (IL)-6 was a good prognostic marker of mortality in patients with COVID-19 (23). On the other hand, the functional capacity of lymphocytes decreases with the decrease in the number of lymphocytes, especially in COVID-19 cases with a severe clinical course (24). It has been observed that COVID-19 progresses more severely in patients with a high NLR value $(11,20,25)$. In a study by Liu et al. evaluating 245 patients, NLR was found to be an independent risk factor associated with high mortality, especially among men (7). In another observational study with 1,859 COVID-19 patients, mortality was found to have a significant correlation with increased NLR, low platelet count and high creatine and D-dimer values (10). We also observed a significant association between NLR and mortality in our study.

In this study, although several clinical and laboratory parameters, such as severe thorax CT findings, leucocyte and neutrophile counts, and ferritin, CRP, creatinine, ALT, AST, GGT, LDH and troponin levels were higher, lymphocyte levels were lower among the mortality group in the univariate analysis, only advanced age, presence of any comorbidity, and higher NLR, CRP, creatinine and GGT values were determined to be associated with high mortality in the multivariable analysis. This is consistent with previous studies reporting an association between high mortality in COVID-19 and higher ferritin, CRP and D-dimer levels reflecting a greater inflammatory response (26, 27). Additionally, we determined that the correlation between low $\mathrm{SpO}_{2}$ with CRP and NLR was also compatible with the association between these two parameters and high mortality in our study.

Liver test abnormalities are more frequently observed in severe cases of COVID-19. Liver injury and liver enzyme abnormalities in COVID-19 may be multifactorial and result from the direct pathogenic effects of the virus, ad- verse drug reactions, higher systemic immune response (cytokine storm), and hypoxia in these patients (28). Elevation of the GGT level and the organ infiltration of IL-6-producing cells are the defining characteristics for patients with the severe COVID-19 $(29,30)$. In a study by Zhang et al., CRP and NLR were correlated with high GGT levels (29). In our study, CRP but not NLR was correlated with GGT, which is consistent with the above-mentioned study. Higher GGT levels at admission, as well as other liver enzymes have been associated with mortality and ICU admission among COVID-19 patients (31). Furthermore, GGT has been found to be a useful biomarker when combined with other laboratory parameters in COVID-19 (32). The biliary epithelium expresses the ACE-2 receptor, which is the known as the binding site of SARS-CoV-2, while the expression in hepatocytes is possibly much lower (33), which is consistent with increased GGT rather than transaminase levels among the patients with COVID-19 in our study. In addition to GGT elevation, an increased creatinine level has also been associated with poor prognosis and may be an independent risk factor of in-hospital death in patients with COVID-19 (34). Furthermore, higher BUN and/or creatinine levels and NLR are independent predictors of severe disease and higher mortality in patients with COVID-19 (35), which is also in agreement with our findings. Liver and kidney dysfunction reflecting multiorgan involvement in COVID-19, possibly due to the direct effect of the SARS-CoV-2 virus or cytokine storm can contribute to the higher mortality associated with the disease.

In conclusion, in COVID-19, at risk patients can be identified in the early period with several simple clinical and laboratory parameters. This evaluation, performed at the time of admission, can contribute to the reduction of mortality through a closer clinical and laboratory follow-up. The hospital mortality rate can be reduced by determining high-risk patients at admission, which would also facilitate early appropriate treatment in these patients. Controlled prospective studies with larger patient 
populations are needed to confirm the prediction of mortality in patients with COVID-19.

\section{Limitations of our study}

Important limitations of our study are its retrospective observational design and the absence of a control group. The patient group included in our study population may not reflect all COVID-19 patients due to the hospitalization of more severe cases, and this may have caused a bias.

Ethics Committee Approval: This study was approved by the Ethical Committee of the Ağrı Education and Research Hospital (Date: 11.12.2020, No:29)

Peer Review: Externally peer-reviewed.

Author Contributions: Conception/Design of Study- O.E., M.B.; Data Acquisition- O.E., F.K.; Data Analysis/InterpretationO.E., Ö.A.; Drafting Manuscript- O.E., M.B.; Critical Revision of Manuscript- O.E., Ö.A., M.B.; Approval and Accountability- O.E., F.K., Ö.A., M.B.

Conflict of Interest: Authors declared no conflict of interest

Financial Disclosure: Authors declared no financial support.

\section{REFERENCES}

1. Huang C, Wang Y, Li X, Ren L, Zhao J, Hu Y, et al. Clinical features of patients infected with 2019 novel coronavirus in Wuhan, China. Lancet 2020;395(10223):497-506. [CrossRef]

2. Zhu N, Zhang D, Wang W, Li X, Yang B, Song J, et al. A Novel Coronavirus from Patients with Pneumonia in China, 2019. N Engl J Med. 2020;382(8):727-33. [CrossRef]

3. Chen N, Zhou M, Dong $X, Q u$ J, Gong F, Han Y, et al. Epidemiological and clinical characteristics of 99 cases of 2019 novel coronavirus pneumonia in Wuhan, China: a descriptive study. Lancet 2020;395(10223):507-13. [CrossRef]

4. Zhou F, Yu T, Du R, Fan G, Liu Y, Liu Z, et al. Clinical course and risk factors for mortality of adult inpatients with COVID-19 in Wuhan, China: a retrospective cohort study [published correction appears in Lancet. Lancet 2020;395(10229):105462. [CrossRef]

5. Pranata R, Huang I, Lim MA, Wahjoepramono EJ, July J. Impact of cerebrovascular and cardiovascular diseases on mortality and severity of COVID-19-systematic review, meta-analysis, and meta-regression. J Stroke Cerebrovasc Dis 2020;29(8):104949. [CrossRef]

6. Ye W, Chen G, Li X, Lan X, Ji C, Hou M, et al. Dynamic changes of D-dimer and neutrophil-lymphocyte count ratio as prognostic biomarkers in COVID-19. Respir Res 2020;21(1):169. [CrossRef]

7. Liu Y, Du X, Chen J, Jin Y, Peng L, Wang H, et al. Neutrophilto-lymphocyte ratio as an independent risk factor for mortality in hospitalized patients with COVID-19. J Infect. 2020;81(1):e6-12. [CrossRef]

8. World Health Organization. Global surveillance for COVID-19 caused by human infection with COVID-19 virus: interim guidance, 20 March 2020. World Health Organization. https://apps.who.int/iris/handle/10665/331506
9. Rodrigues $\mathrm{JCL}$, Hare SS, Edey A, Devaraj A, Jacob J, Johnstone $A$, et al. An update on COVID-19 for the radiologist - A British society of Thoracic Imaging statement. Clin Radiol 2020;75(5):323-5. [CrossRef]

10. Chen L, Yu J, He W, Chen L, Yuan G, Dong F, et al. Risk factors for death in 1859 subjects with COVID-19. Leukemia 2020;34(8):2173-83. [CrossRef]

11. Liang W, Liang $H, O u$ L, Chen B, Chen A, Li C, et al. Development and Validation of a Clinical Risk Score to Predict the Occurrence of Critical Illness in Hospitalized Patients With COVID-19. JAMA Intern Med 2020;180(8):1081-9. [CrossRef]

12. Zhou F, Yu T, Du R, Fan G, Liu Y, Liu Z, et al. Risk factors for severity and mortality in adult COVID-19 inpatients in Wuhan. J Allergy Clin Immunol 2020;146(1):110-8. [CrossRef]

13. Grasselli G, Greco M, Zanella A, Albano G, Antonelli M, Bellani G, et al. Risk Factors Associated With Mortality Among Patients With COVID-19 in Intensive Care Units in Lombardy, Italy. JAMA Intern Med 2020;180(10):1345-55. [CrossRef]

14. Durmus E, Kivrak T, Gerin F, Sunbul M, Sari I, Erdogan O. Neutrophil-to-Lymphocyte Ratio and Platelet-toLymphocyte Ratio are Predictors of Heart Failure. Arq Bras Cardiol 2015;105(6):606-13. [CrossRef]

15. Dolan RD, McSorley ST, Horgan PG, Laird B, McMillan DC. The role of the systemic inflammatory response in predicting outcomes in patients with advanced inoperable cancer: Systematic review and meta-analysis. Crit Rev Oncol Hematol 2017;116:134-46. [CrossRef]

16. Zhang F, Ren Y, Fu W, Wang Y, Qian J, Tao C, et al. Association between neutrophil to lymphocyte ratio and blood glucose level at admission in patients with spontaneous intracerebral hemorrhage. Sci Rep 2019;9(1):15623. [CrossRef]

17. Deng $Y$, Fan $X, \operatorname{Ran} Y, X u X$, Lin L, Cui B, et al. Prognostic impact of neutrophil-to-lymphocyte ratio in cirrhosis: $A$ propensity score matching analysis with a prespecified cutpoint. Liver Int 2019;39(11):2153-63. [CrossRef]

18. Bartlett EK, Flynn JR, Panageas KS, Ferraro RA, Sta Cruz JM, Postow MA, et al. High neutrophil-to-lymphocyte ratio (NLR) is associated with treatment failure and death in patients who have melanoma treated with PD-1 inhibitor monotherapy. Cancer 2020;126(1):76-85. [CrossRef]

19. Zhang HF, Ge YL, Wang HY, Zhang Q, Li WQ, Chen Y, et al. Neutrophil-to-Lymphocyte Ratio Improves the Accuracy and Sensitivity of Pneumonia Severity Index in Predicting 30-Day Mortality of CAP Patients. Clin Lab 2019;65(10). 10.7754/Clin.Lab.2019.190226. [CrossRef]

20. Costa S, Bevilacqua D, Cassatella MA, Scapini P. Recent advances on the crosstalk between neutrophils and $B$ or $T$ lymphocytes. Immunology 2019;156(1):23-32. [CrossRef]

21. Henry B, Cheruiyot I, Vikse J, Mutua V, Kipkorir V, Benoit J, et al. Lymphopenia and neutrophilia at admission predicts severity and mortality in patients with COVID-19: a metaanalysis. Acta Biomed 2020;91(3):e2020008.

22. Li T, Lu H, Zhang W. Clinical observation and management of COVID-19 patients. Emerg Microbes Infect 2020;9(1):68790. [CrossRef]

23. Luo M, Liu J, Jiang W, Yue S, Liu H, Wei S. IL-6 and CD8+ $T$ cell counts combined are an early predictor of inhospital mortality of patients with COVID-19. JCl Insight 2020;5(13):e139024. [CrossRef] 
24. Diao B, Wang C, Tan Y, Chen X, Liu Y, Ning $L$, et al. Reduction and Functional Exhaustion of T Cells in Patients With Coronavirus Disease 2019 (COVID-19). Front Immunol 2020;11:827. [CrossRef]

25. Xia X, Wen M, Zhan S, He J, Chen W, Nan Fang Yi et al. An increased neutrophil/lymphocyte ratio is an early warning signal of severe COVID-19. J South Med Univ 2020;40(3): 333-6.

26. Huang I, Pranata R, Lim MA, Oehadian A, Alisjahbana B. C-reactive protein, procalcitonin, D-dimer, and ferritin in severe coronavirus disease-2019: a meta-analysis. Ther Adv Respir Dis 2020;14:1753466620937175. [CrossRef]

27. Evlice O, Kuş F, Bektas M. Persistent Symptoms After Discharge of COVID-19 Patients. Infect Dis Clin Microbiol 2021;3(1):22-9. [CrossRef]

28. Ali N, Hossain K. Liver injury in severe COVID-19 infection: current insights and challenges. Expert Rev Gastroenterol Hepatol 2020;14(10):879-84. [CrossRef]

29. Klocperk A, Bloomfield M, Parackova Z, Zentsova I, Vrabcova P, Balko J, et al. Complex Immunometabolic Profiling Reveals the Activation of Cellular Immunity and Biliary Lesions in Patients with Severe COVID-19. J Clin Med 2020;9(9):3000. [CrossRef]

30. Zhang Y, Zheng L, Liu L, Zhao M, Xiao J, Zhao Q. Liver impairment in COVID-19 patients: A retrospective analysis of 115 cases from a single centre in Wuhan city, China. Liver Int 2020;40(9):2095-103. [CrossRef]
31. Grasselli G, Zangrillo A, Zanella A, Antonelli M, Cabrini L, Castelli A, et al. Baseline Characteristics and Outcomes of 1591 Patients Infected With SARS-CoV-2 Admitted to ICUs of the Lombardy Region, Italy. JAMA 2020;323(16):1574-81. [CrossRef]

32. Shao T, Tong Y, Lu S, Jeyarajan AJ, Su F, Dai J, et al. $\gamma$-Glutamyltransferase Elevations Are Frequent in Patients With COVID-19: A Clinical Epidemiologic Study. Hepatol Commun 2020;4(12):1744-50. [CrossRef]

33. Beyerstedt S, Casaro EB, Rangel ÉB. COVID-19: angiotensin-converting enzyme 2 (ACE2) expression and tissue susceptibility to SARS-CoV-2 infection. Eur J Clin Microbiol Infect Dis 2021;40(5):905-19. [CrossRef]

34. Wu C, Chen X, Cai Y, Xia J, Zhou X, Xu S, et al. Risk Factors Associated With Acute Respiratory Distress Syndrome and Death in Patients With Coronavirus Disease 2019 Pneumonia in Wuhan, China. JAMA Intern Med 2020;180(7):934-43. [CrossRef]

35. Ok F, Erdogan O, Durmus E, Carkci S, Canik A. Predictive values of blood urea nitrogen/creatinine ratio and other routine blood parameters on disease severity and survival of COVID-19 patients. J Med Virol 2021;93(2):786-93. [CrossRef] 